\title{
FIRST NESTING OF COMMON RAVENS IN THE SASKATOON BIRD AREA
}

MARTEN J. STOFFEL, Box 183, RR\#4, Saskatoon, SK S7K 3J7

On June 11, 1998, I encountered a family of three young ravens, barely able to fly, beneath the railway bridge on the west side of the South Saskatchewan River east of Warman. I looked without success for a large nest in adjacent trees, but did not think to search the railway bridge structure itself. Although the nest was not found, the barely flying young constituted the first documented breeding record for the Saskatoon Bird Area (SBA, $51^{\circ} 32^{\prime}$ to $52^{\circ}$ $30^{\prime}$ north latitude and $106^{\circ}$ to $107^{\circ} 30^{\prime}$ west

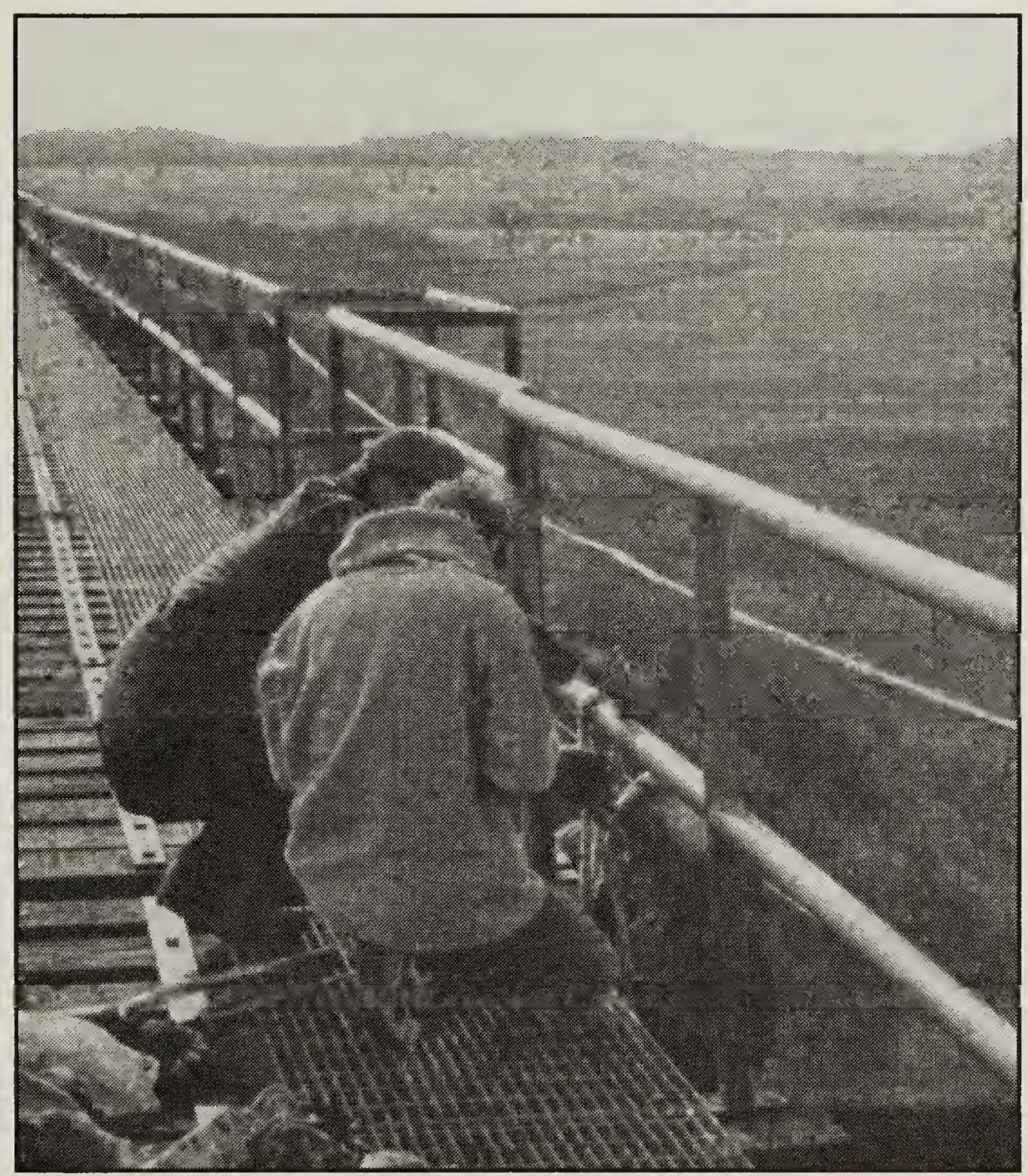

Figure 1. Martin Gérard (in helmet) descending to band the Great Horned Owl chicks in previous raven nest on the railway bridge east of Warman.
Lyle Doell

longitude). In 2002, Lyle Doell found that the Great Horned Owls had preempted the raven nest on the bridge and informed Martin Gérard who then banded three young Great Horned Owls on the former raven nest (Figures 1 and 2).

On 18 June 2001, I found a family of three young ravens, able to fly, more than 1 $\mathrm{km}$ west of the Sterling Pulp Chemicals plant at the corner of Wanuskewin Road and $71^{\text {st }}$ Street in the north industrial area

of Saskatoon. Again, I did not even entertain the possibility that they had nested in a building, although in retrospect that is the best explanation.

The year 2002 was the "year of the raven." Six successful Common Raven nest attempts were reported within the SBA, and another two nests were found within 10 $\mathrm{km}$ of the north boundary of the SBA. The first nest was on a metal platform of an exterior staircase in a building being demolished at the former Interprovincial $\mathrm{Co}$ operatives (IPCO) herbicide plant, adjacent to the Sterling Pulp Chemicals plant. The nest was first 


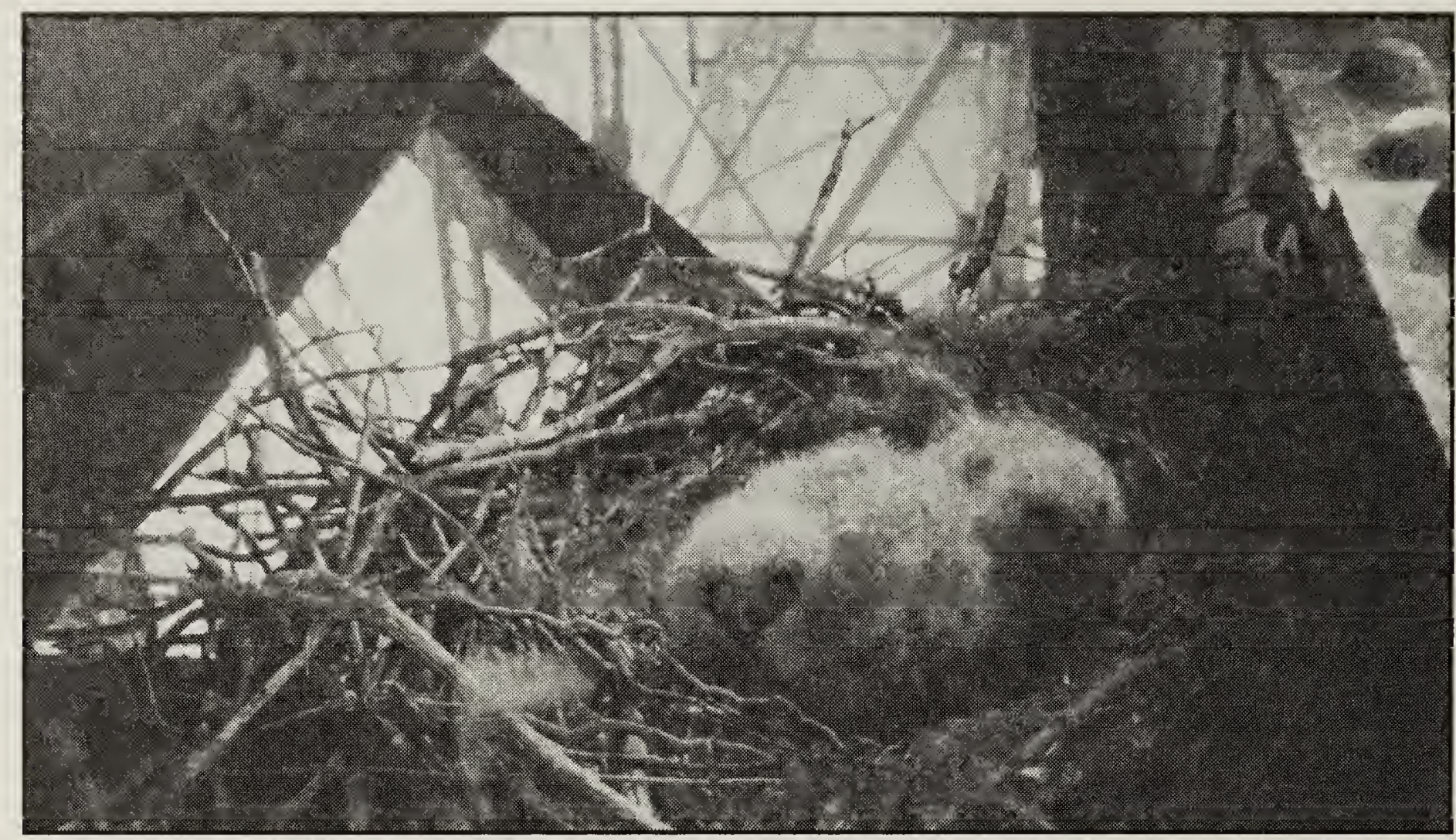

Figure 2. Great Horned Owl chicks in previous raven nest under the railway bridge east of Warman.

Lyle Doell

called to the attention of Gary Bortolotti and Ralph Bock. It was $1.5 \mathrm{~m}$ in diameter, and had contained 5 eggs when the workmen pulled it down on April 20. When the ravens rebuilt on the same site, the workers moved the nest to a nearby structure; the ravens picked up every stick and moved each one back! The persistent adults then built on another stairwell, then on the roof of the building and finally, when the demolition of the building was delayed, in an open window sill facing east, $7.5 \mathrm{~m}$ above ground. Four nearly- mature young from this delayed re-nesting were banded on 13 June.

The second nest, $10.5 \mathrm{~m}$ above ground in an Aspen Poplar on the north shore of Rice Lake, east-south-east of Asquith, was found by Peter Jonker on May 25. The two fullgrown young in the nest were banded on May 31. The third nest, $7 \mathrm{~m}$ above ground in an Aspen Poplar, also east of Asquith, contained three small young, barely large enough to hold a band, on May 31. I found the fourth nest $9 \mathrm{~m}$ above ground in an Aspen Poplar across the road from the northeastern edge of Dalmeny on May 24; three young were banded on June 2 . The fifth pair, south of Dalmeny on 11 June, had four young flying fairly well, and without help I was only able to catch and band one. The sixth record was from $3 \mathrm{~km}$ east of Dundurn on Highway 663, where four young ravens, flying too well to catch but still being fed by two adults, were spotted by Mary Houston and Doris Ihrig on 29 June.

Immediately north of the SBA, Art Lepp found two nests. The first was $14.5 \mathrm{~m}$ above ground in an Aspen Poplar north of Hepburn, where three young were banded on 2 June. The second, $13.5 \mathrm{~m}$ above ground in an aspen near Hague, had been active on 13 May. On 2 June, the nest was empty, and there was much "whitewash" excreta below the empty nest. A search of the aspen bluff revealed no young out of the nest. They most probably had fledged early in spite of the late, cold spring and had already dispersed, but the possibility of predation by a Great Horned Owl or raccoon cannot be excluded.

In all, Stuart Houston and I banded 16 flightless young in 2002, 13 within the SBA. Our best guess is that the pairs 
found represent only the tip of the iceberg, and that more detailed searches in heavy aspen might have detected more. Do these recent nest records, part of a general southward movement across the province, after an absence of more than a century, mean that this species is now here to stay?

When Bison roamed the plains, the Common Raven was more numerous than the American Crow. ${ }^{1}$ When Thomas Blakiston of the Palliser expedition went south from Fort Carlton on a bison hunting expedition in 1858 , he found several raven nests, at least one of them beside one of the Anerley lakes (only $18 \mathrm{~km}$ south of the southern boundary of the SBA) on April 29. ${ }^{2}$

\section{Acknowledgements}

I thank Gary Bortolotti for information on the early nest attempts at the IPCO plant, Lyle and Don Doell for information and a photograph, and Stuart Houston for keyboarding and editorial assistance.

1. C. S. HOUSTON and J. K. SCHMUTZ. 1999. Changes in bird populations on Canadian grasslands. Studies in Avian Biology 18: 87-94.

2. C. S. HOUSTON. 1976. A bird watcher's outing in 1858. Saskatchewan History 29:14-25.

\section{A MAGPIE BAND-RELEASE PROJECT IN THE CALGARY AREA, 1949}

JIM SALT (compiler and editor), 464 Nelson Street, Victoria, BC V9A 6P4, jrsalt@Pacificcoast.net

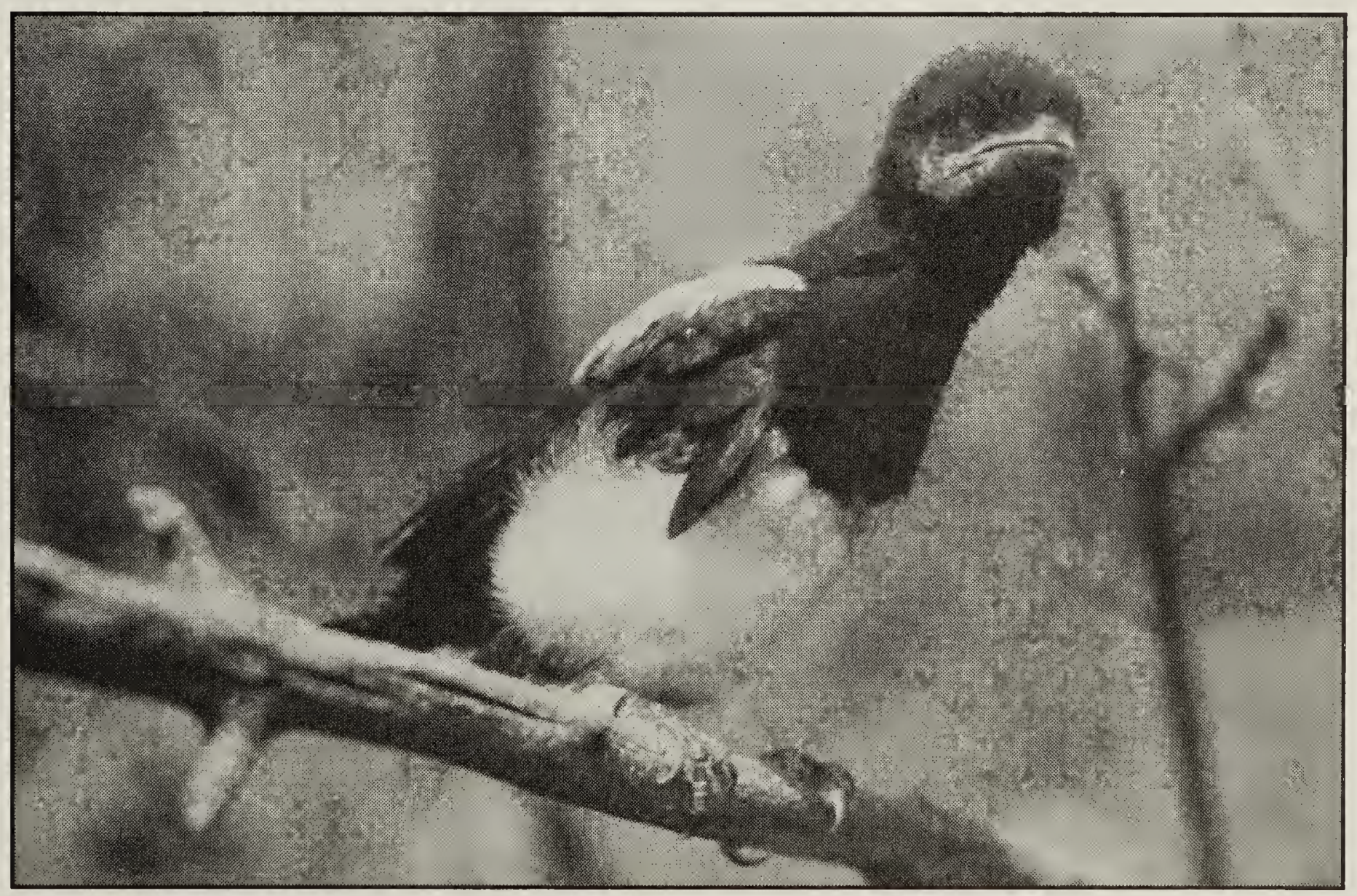

